\title{
AN ATTORNEY FINE: A SANCTION TO ENSURE COMPLIANCE WITH COURT CALENDAR ORDERS
}

[C]onscious of his own rights, he asked through the telephone what would happen if he failed to put in an appearance. "We shall know where to find you," was the answer. "And shall I be punished for not having come of my own accord?" asked $\mathrm{K}$., and smiled in anticipation of the reply. "No," was the answer. "Splendid," said K., "then what motive could I have for complying with this summons?" "It is not usual to bring the powers of the Court upon one's own head," said the voice, becoming fainter and finally dying away. "It is very rash not to do so," thought $\mathrm{K}$. as he hung up; "for after all one should try to find out what those powers are."1

\section{INTRODUCTION}

The concentration of trial practice in a relatively small percentage of the bar has been blamed as one of the causes of court delay. ${ }^{2}$ An attorney with a large trial practice may frequently be scheduled for trial or for a pretrial or motion hearing in two courts at the same time-making a continuance necessary in one of the cases. If the court has no other business pending for immediate hearing, involuntary judicial idleness results. ${ }^{3}$ The basic solution "is simply that the Court in scheduling recognize the concentration as a fact of life and seek to accommodate it." 4 But this in itself is not enough. For after the court has done its best to arrange the trial calendar in light of the conflicting demands on counsel, what happens when counsel is still unable to appear? Accommodation can only go so far. ${ }^{5}$ At some point the court must exercise its powers to compel appearance. It is to be suspected that in the past a judgeadministered lecture combined with judicial tolerance has been considered an adequate antidote for such derelictions. ${ }^{6}$ As a result there have been few cases

1 KaFka, The Trual 290 (Modern Library ed. 1925).

2 Zeisel, Kalven \& Bucheolz, Delay IN the Court, 190-200 (1959) discusses the concentration of the trial bar and its relation to delay. Figures for the Supreme Court of New York County [Manhattan] showed that the busiest $5 \%$ of the plaintiff's bar made $22.5 \%$ of the court appearances, while the busiest $5 \%$ of the defendant's bar made $24.8 \%$ of the court appearances. Id. at 194-95.

3 Id. at 195-96.

4 Id. at 199.

5 "Ultimately the court has the power to compel lawyers to go to trial and thus to force them, if necessary, to turn some of their cases over to other lawyers or to add additional trial personnel to their own firm." Ibid. The authors are here speaking of the power to dismiss.

6 This point was made by McLaughlin, J., in Gamble v. Pope \& Talbot, Inc., 307 F.2d 729, 732 (3d Cir. 1962):

"On occasion there is a slip up .... Usually it occurs where a date is not entered, or per- 
dealing with the problem. But repeated judicial admonitions administered without the possibility of effective sanctions soon become empty words.

The traditional sanctions available to ensure compliance with calendar orders are dismissal, default judgment and imposition of the adversary's additional costs. ${ }^{7}$ But dismissal or default result in a judgment not on the merits but rather one based on the necessities of judicial housekeeping. This is not in accord with "a desire to reduce technicalities to a minimum and to decide all cases on their merits as expeditiously as possible."8 At the same time, the additional costs occasioned the adversary by the attorney's dereliction may be small-particularly in the case of a paper filed late-so that to impose them on the non-complying party is to impose no sanction at all. In Gamble $v$. Pope \& Talbot, Inc., ${ }^{9}$ a district court attempted to find a workable alternative

haps not carried over, or is erroneously noted; sometimes where a paper or letter is filed prematurely and forgotten until some independent reminder brings it to light .... When it happens, they [lawyers] are embarrassed and troubled. In good faith they do what can be done to make amends. As long as a lawyer practices, once in a great while, he will be haunted by the thought that he missed a filing date. His primary distress is not over punishment but that he has neglected a duty." The informality with which the problem has been handled is revealed by remarks of Judge Mellvaine of the Western District of Pennsylvania at a seminar on procedure held at the Southern Methodist University School of Law in 1961: "When counsel does not appear at pretrial, we again enter the same default order, but before we put it back on the list it often is accompanied by an order having the attorney pay as penalty a proper attorney fee to the other party who had appeared, and who has to make a second appearance before the court.

"We did find that some lawyers were reluctant to accept fees from other lawyers which were levied in the nature of a penaity, and in order to put some sting in the sanction Chief Judge Gourley and I, as well as certain other members of the Court, have from time to time given the attorney the right to do something which he should have done before only upon the payment of a fee to the library fund." 29 F.R.D. 191, 411 (1961). Lower federal courts obtain the power to relieve parties from the consequences of their failure to appear through the provisions of Rule $6(\mathrm{~b})(2)$ of the Fed. R. Civ. P.: "When by these rules or by a notice given thereunder or by order of court an act is required or allowed to be done at or within a specified time, the court for cause shown may at any time in its discretion ... (2) upon motion made after the expiration of the specified period permit the act to be done where the failure to act was the result of excusable neglect. ..."

7 The power to dismiss is recognized by Rule 41 of the Fed. R. Civ. P. Rule 55 recognizes that default may be entered for failure "to plead or otherwise defend." Federal courts are not empowered to impose the adversary's additional costs on the derelict party by statute, hence the imposition of costs is based on the power of the court to ensure fairness between litigants. The power of federal courts to make the party at fault pay the other party's costs, including attorney's fees, occasioned by his non-compliance with a court rule or order is asserted in dictum in Matheny v. Porter, 158 F.2d 478 (10th Cir. 1946). For a discussion of the use of sanctions in relation to pretrial, see $60 \mathrm{MrCH}$. L. REv. 223 (1961). In relation to discovery, see Rosenberg, Sanctions to Effectuate Pretrial Discovery, 58 CoLum. L. Rev. 480 (1958).

8 Holtzoff, A Judge Looks At the Rules After Fifteen Years of Use, 15 F.R.D. 155 (1954). "The adoption of the new Federal Rules of Civil Procedure in 1938 was an epoch-making event in the history of jurisprudence. ... It brought about a new era in the administration of justice,-an era characterized by a desire to reduce technicalities to a minimum and to decide all cases on their merits as expeditiously as possible."

9191 F. Supp. 763 (E.D. Pa. 1961), rev'd, 307 F.2d 729 (3d Cir.), cert. denied, 371 U.S. 888 (1962). 
by imposing a fine directly on the derelict attorney. In that case the attorney for the defendant failed to file a pretrial memorandum on the date specified by the standing order of the court.10 Upon receipt of regular notice of the impending pretrial conference he reviewed his files, discovered the omission and proceeded to prepare a memorandum which he filed the day before the conference, ten months overdue. 11 The pretrial conference was apparently held as scheduled. The plaintiff moved to strike the defendant's pretrial memorandum. The judge felt this would result in a virtual default judgment and was unacceptable.12 So in addition to the imposition of the plaintiff's costs on the defendant he made an assessment on the defendant's attorney.

In view of the time of judicial employees of the Government wasted as a result of the late filing of this memorandum, a fine shall be paid by counsel for defendant to the United States of America .... . Such a fine will be more substantial in subsequent cases of such long delay in filing a pre-trial memorandum, but the fact that this is the first time in the experience of the pre-trial judge that a fine has been required is being taken into consideration in this case. 13

The attorney appealed. The Third Circuit, sitting en banc, reversed the lower court on the ground that the district court had exceeded its power by imposing a criminal sanction without legislative authority for conduct that did not amount to contempt of court. ${ }^{14}$ Two judges dissented. This comment will deal

10 Pretrial standing order, adopted Oct. 1958. 1 FED. Rutes SeRv. 2d 1183:

"The civil pretrial list shall be published at least 90 days in advance of the period during which pretrial conferences shall be held. Not later than 30 days after the publishing of said list, counsel for plaintiff shall file a written pretrial memorandum with the clerk of the court and serve two copies on all other counsel of record.

"Within 30 days of receipt of such pretrial memorandum, all counsel served with plaintiff's memorandum shall file a written pretrial memorandum with the clerk of the court and serve two copies on all other counsel of record."

11307 F.2d at 730 .

12191 F. Supp. at 764-65.

13 Id. at 765. The standing order of the court, adopted Feb. 1960, 3 FED. RULES SERV. 2d 1154, made provision for such a fine. "For failure to appear at a pretrial conference, or to participate therein, or to prepare therefore, the court, in its discretion, may make such order with respect to the imposition of fines, costs and counsel fees, as is just and proper; with respect to the continued prosecution of the cause (complaint, cross-claim or counterclaim), a dismissal may be entered, or as to the defense, the preclusion of all or any part thereof, as is likewise just and proper." The only difference between this standing order and the previous order of the court on the subject, 23 FED. RULES SERV. 814 (1956), is the added provision for the imposition of fines. The existence of the standing order, however, is relevant only in so far as it gave fair notice to the bar of the court that such a sanction would be imposed. If the court did not have the power to fine an attorney then it did not have the power to promulgate a rule providing for such a fine.

14307 F.2d 729 (3d Cir. 1962). Judge McLaughlin wrote the court's opinion in which Judges Staley and Smith concurred. This opinion found an attorney fine both undesirable and in excess of the court's power. Judges Hastie and Kalodner concurred in the result only on the ground that the fine "imposed a criminal sanction without legislative authority for conduct which did not amount to contempt of court." Id. at 733. Judges Biggs and Goodrich each filed dissenting opinions approving of the fine as a proper exercise of the court's disciplinary power. 
with: (1) the question of whether such a fine is desirable and (2) whether such a fine is within the power of a federal district court.

\section{The NeEd for AN ATTORNEY FINE}

An attorney fine as a sanction to ensure compliance with court calendar orders is desirable because it provides an alternative to dismissal or default. An example of the severity of dismissal as a sanction is Link v. Wabash R.R.15 In that case the district court dismissed the plaintiff's personal injury action after his attorney had attempted to get a pretrial conference rescheduled. The attorney's excuse was "that he was busy preparing papers to file with the [Indiana] Supreme Court," that "he wasn't actually engaged in argument and that he couldn't be ... [there] by 1:00 o'clock [for the pretrial conference], but ... would be ... [there] either Thursday afternoon or any time Friday if it could be reset."16 The Seventh Circuit affirmed the dismissal with Judge Schnackenberg dissenting. 17 The majority considered the dismissal an exercise of the district court's "inherent power to enforce its rules, orders or procedures and to impose appropriate sanctions for failure to comply." 18 Courts must be able to enforce the operation of trial procedure or, observed the court, "the orderly administration of justice will be removed from control of the trial court and placed in the hands of counsel."19 Judge Schnackenberg answered that dismissal was not necessary because "a district court does not lack disciplinary authority over an attorney." $20 \mathrm{He}$ did not say what exercise of the disciplinary authority would be appropriate for this situation. However, the fine imposed in the Gamble case comes immediately to mind.

The Supreme Court affirmed the Seventh Circuit in the Link case with Justices Warren, Douglas and Black dissenting. 21 The majority read the record as justifying the dismissal for "want of prosecution," instead of for the single failure to appear at the pretrial conference as the two courts below had done. By so reading the record the majority made the problem a simple one: It is perfectly sensible that the plaintiff should not be given what he has not even made an effort to obtain. As a result the majority never passed on the question whether a single failure to appear is in itself sufficient to justify dismissal.22 In his dissent Mr. Justice Black objected to the majority's reading of the record. But he also took the position that even if this interpretation of the record was correct, the dismissal was not justified because: "[T] say that the sins or faults or delinquencies of a lawyer must always be visited upon his client so as to impose tremendous financial penalties upon him, as here, is to ignore the

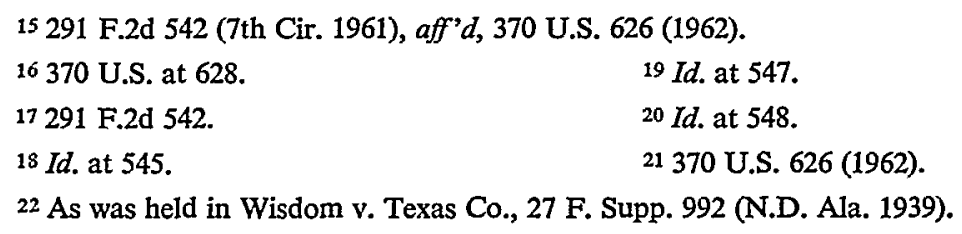


practicalities and realities of the lawyer-client relationship. ... The average individual called upon, perhaps for the first time in his life, to select a lawyer to try a lawsuit may happen to choose the best lawyer or he may happen to choose one of the worst, [but] he has a right to rely at least to some extent upon the fact that a lawyer has a license." 23 To this the majority answered in terms of simple agency principles: "Petitioner voluntarily chose this attorney as his representative in the action, and he cannot now avoid the consequences of the acts or omissions of this freely selected agent."24 Although the mechanics of the agency analysis do not meet the thrust of Mr. Justice Black's opinion, the reasons behind the agency rule do. There is probably no fact more basic to our adversary system than the necessary fact that litigants suffer daily for the blunders of their attorneys. But Mr. Justice Black qualified his position by the insertion of the phrase "to some extent." The area of compliance with calendar orders might be one that could reasonably fall outside the operation of the agency rule. Does not a litigant have a right to rely on his lawyer "to some extent"? He may at least expect that his lawyer will represent him.

Mr. Justice Black's own proposal for the enforcement of calendar orders is the adoption of the rule that "no client is ever to be penalized . . . because of the conduct of his lawyer unless notice is given to the client himself that such a threat hangs over his head." 25 This is reminiscent of the demand of the medieval courts that a litigant avow the words of his pleader. ${ }^{26}$ But this procedure would supply an ineffective sanction, since the client could always disclaim his attorney's action, most likely on his attorney's advice, if the action would cost him the case. But what about a fine? Judge McLaughlin, writing for the Third Circuit in Gamble v. Pope \& Talbot, Inc., considered the imposition of a fine as a sanction "the first giant step in stripping a lawyer of his independence and leaving him, his client and the latter's cause of action to the ukase of the court."27 Stripped of its color this statement reduces to the proposition that courts should not interfere in the attorney-client relationship. In reversing a contempt penalty imposed upon an attorney for an overzealous

23370 U.S. at $646-47$.

24 Id. at 633-34. The majority in the court of appeals took the same view. "The short answer to this is that the action or lack of action on the part of counsel is that of his client." 291 F.2d at 546.

25370 U.S. at 648.

26 "In those days one of the chief advantages of having a pleader to speak for one before the court lay in the fact that it was possible to disavow a mistake made by the pleader, and so avoid losing the action by a verbal slip." 2 HoLDSwORTH, A HisTORY OF ENGLISH LAw 262 (1909). He is here speaking of the time of Henry I (1100-1135). Maitland draws similar conclusions for the reign of Edward II (1307-1327). "What he says does not bind his client unless and until the client by himself or his attorney 'avows' it." Maitland, 20 SELDEN SOCIETY lxvi (1905).

27307 F.2d at 733. 
presentation of his client's cause the Supreme Court has observed that it is "essential to a fair administration of justice that lawyers be able to make honest good-faith efforts to present their clients' cases."28 It would be unacceptable for courts to fine attorneys for making bad arguments. Vigorous advocacy can flourish only where attorneys are left free to represent their clients win or lose. 29 In the long run economic sanctions operate to ensure excellence. Good lawyers acquire clients, bad lawyers lose them and negligent lawyers are subject to damages for malpractice, at least where their ex-clients can recover. ${ }^{30}$ But to push the argument so far is to expose its inapplicability. A forgetful failure to comply with a calendar order is significantly different from bad argument. It is hardly necessary to encourage vigorous advocacy by protecting from court interference derelictions that the attorney does not even intend.

In Link v. Wabash R.R.31 it was the plaintiff's attorney who failed to appear. If the case had involved the defendant's attorney could the court have defaulted as easily as it dismissed? The plaintiff seeks the assistance of the court in enforcing his rights. He carries the burden of litigation. The defendant on the other hand has come into court involuntarily. As a result it is reasonable to demand a greater degree of cooperation from the plaintiff than from the defendant. This is reflected in the structure of the Federal Rules of Civil Procedure. Rule 41 provides for an involuntary dismissal "for failure of the plaintiff... to comply with these rules or any order of the court," upon motion of the defendant. No corresponding rule exists for defendants.

28 In re McConnell, 370 U.S. 230, 236 (1962).

${ }^{29}$ Rostow, The Lawyer and His Client, 48 A.B.A.J. 25, 28 (1962): "It is our [American and English] common conviction that the legal process, conducted by independent judges, will be incapable of resisting public or private tyranny unless the judges are aided in the course of trials, and in all other aspects of the work of the profession, by equally independent lawyers, who have been schooled to provide a fearless and intransigent enquiry into every relevant circumstance of the problem being dealt with."

30 The efficacy of malpractice suits as a means of ensuring professional diligence is to be doubted. There seems to be general agreement that there are few disbarment cases. How this is to be interpreted depends on one's view of the profession. "Why is it that the attorney, who has been described as 'one who gets two other men to strip for a fight and then takes their clothes,' is seemingly exempt from the professional liability suit?" Comment, Malpractice at the Bar, 26 TENN. L. REv. 525 (1959). "Considering the immensity of the matters in which trust is reposed in lawyers by clients, business and personal alike, the comparative dearth of malpractice actions against attorneys would seem to testify that the great majority of lawyers maintain a high ethical standard and are not wanting in reasonable diligence in respect to matters entrusted to them." Gardner, Attorneys' Malpractice, 6 CLEv.-MAR. L. REv. 264, 267 (1957). But even if the threat of malpractice suits does ensure professional diligence, it does so only by placing upon the client the risk of additional litigation and of the attorney's insolvency. If the attorney carries malpractice insurance, which removes the risk of insolvency, then malpractice suits operate to encourage attorney diligence only as they are reflected in higher insurance premiums-one more level removed from the trial process itself.

31 291 F.2d 542 (7th Cir. 1961), aff'd, 370 U.S. 626 (1962). 
Rule 37 provides for default and dismissal in discovery situations. And Rule 55 provides for entry of default judgment for failure "to plead or otherwise defend." Although the phrase "otherwise defend" is ambiguous, it clearly envisages a less exacting standard than Rule 41.32 But it is in the defendants' bar where the greatest concentration of trial practice is found. ${ }^{33}$ In Gamble, unlike Link, it was the defendant's attorney who failed to comply with the calendar order, and his failure went only to the filing of a pretrial memorandum-still three months before trial-rather than an actual failure to appear. In these circumstances the conclusion of the district court that a default would be improper seems correct. ${ }^{34}$ Nor is it possible to see how the late pretrial memorandum occasioned any additional expenses for the plaintiff-except those caused by the hearing on his own motion to strike the defendant's memorandum. As a result, in Gamble an attorney fine was the only effective and reasonable sanction possible. Furthermore, if limitations on the power of a district court to utilize dismissal as a sanction in situations such as that in Link are to be expanded, 35 then an attorney fine would not only be a useful, but a necessary sanction in order to ensure appearance at court hearings. But does a federal district court have the power to impose an attorney fine?

\section{THE POWER to Impose CosTS}

The Second Circuit, unlike the Third, has imposed a monetary penalty on an attorney for failure to comply with a court calendar order. In Bardin $v$. Mondon ${ }^{36}$ plaintiff's attorney was not ready for trial in the Southern District of New York on the scheduled date and refused to proceed to trial when directed to do so by the judge. His excuse was that his associate who was to try

32 Bass v. Hoagland, 172 F.2d 205 (5th Cir.), cert. denied, 338 U.S. 816 (1949), found that the phrase "otherwise defend" did not extend to a failure to appear at trial. "When ... [the defendent] by his attorney filed a denial of the plaintiff's case neither the clerk nor the judge could enter a default against him." Id. at 210. The phrase has been held not to extend to a failure to appear for the scheduling of trial. Olsen v. International Supply Co., 22 F.R.D. 221 (D.C. Alaska 1958). Nor has the phrase been held to extend to a failure to appear at pretrial when the defendant's counsel withdrew without the defendant's knowledge. Stafford v. Dickison, 374 P.2d 665 (Hawaii 1962).

33 ZEISEL, KALVEN \& BUCHHOLZ, op. cit. supra note 2. "The concentration of cases among defense lawyers is, as one might expect, considerably greater than among plaintiff lawyers. This is but a reflection of the high degree of concentration among defendants (defending insurance companies and self-insured corporations) as against any concentration among plaintiffs." Id. at 195.

34191 F. Supp. at 764-65.

35 State courts have ruled, in situations similar to the Link case, that dismissal is improper. Beasley v. Girten, 61 So. 2d 179 (Fla. 1952); Luplow v. Aubrey Cleaners \& Dyers, Inc., 115 N.W.2d 110 (Mich. 1962); Allegro v. Afton Village Corp., 9 N.J. 156, 87 A.2d 430 (1952); Manekofsky v. Baker, 169 A.2d 376 (R.I. 1961). The height of judicial impotence was reached in Long v. Railroad Transfer Serv., 302 F.2d 555 (7th Cir. 1962), when attorneys for both the plaintiff and the defendants failed to appear for trial due to a misunderstanding. The circuit court reversed the trial court's dismissal, pointing out that the defendants' attorneys were as much at fault as the plaintiff's.

36298 F.2d 235 (2d Cir. 1961). 
the case was in the hospital. The district judge dismissed the case with prejudice. The circuit court found that the dismissal was not an abuse of discretion in view of the calendar problem confronting the Southern District. ${ }^{37}$ "Nevertheless," continued the court,

appellants have suffered from the sins of their counsel, sins of which they probably knew nothing at all. Although a litigant is ordinarily bound by the mistakes of his counsel, in this instance, we think it would serve a better purpose to require counsel himself to pay for the inconveniences caused by his own dilatory conduct. 38

The court allowed the case to be dismissed without prejudice on the condition that the attorney pay all trial and appellate court costs taxed to his clients and that he pay an "additional $\$ 100$ in costs to be imposed by the District Court." 39 In support of this action the court relied on the following statutory language: "Any attorney ... who so multiplies the proceedings in any case as to increase costs unreasonably and vexatiously may be required by the court to satisfy personally such excess costs." 40 On its face the statute is ambiguous as to whether it refers to excess costs of the court or the adversary party. The only case actually interpreting the statute, Motion Picture Patents Co. v. Steiner, ${ }^{41}$ seems to imply that it means the excess costs of the adversary party. In that case an award of 150 dollars to each of two defendants by reason of the prolonged examination of witnesses by the plaintiff's counsel was reversed on the ground that the character and amount of the additional expense were not stated. The court observed that it was "unable to find in $\S 982$ [present $\$ 1927$ ] authority for allowing an arbitrary sum ... to be inserted in the judgment and paid by the complainants to the defendants." 42 Similar reasoning could be applied to the 100 dollars assessed in the Bardin case, which was apparently arbitrary in amount.

37 Id. at $235-38$.

38 Id. at 238.

$39 \mathrm{Ibid}$. A case reaching a similar conclusion is United Sheeplined Clothing Co. v. Arctic Fur Cap Corp., 165 F. Supp. 193 (S.D.N.Y. 1958). In that case the defendant failed to appear on the date set for the taking of depositions because his attorney had failed to notify him. "Under these circumstances," reasoned the court, "it would seem unfair to the defendant and improper to dismiss the answer and counterclaim and enter a default judgment against the defendant. Any such failure of the defendant to appear was due to the neglect of defendant's attorney rather than unwillingness on the part of the defendant to appear for the deposition." Id. at 194. The court ordered the defendant's attorney to pay $\$ 50$ "costs" to the plaintiff for "neglect of his professional duties." Ibid.

4028 U.S.C. $\$ 1927$ (1958). The court also cited calendar rule 16 of the District Court for the Southern District of New York, 4 FED. RuLES SERV. 2d 1163 (1961), which, after making provision for other sanctions (preclusion orders and dismissal or default) continues: "(c) Imposition of Costs on Attorneys. If counsel fail to comply with any of the Calendar Rules and the judge finds that the sanctions in section (a) and (b) above are either inadequate or unjust to the parties in light of the facts or circumstances, he may, in addition to, or in lieu of, such sanctions assess reasonable costs directly against counsel whose action has obstructed the effective administration of the court's business." However the court cited only 28 U.S.C. $\$ 1927$ in support of the district court's power to promulgate such a rule.

41201 Fed 63 (2d Cir. 1912).

$42 \mathrm{Id}$. at 65. 
The legislative history of section 1927 suggests that the phrase "multiplies the proceedings" refers to multiplying the number of actions, and that the payment of costs is not to the adversary party, but to the court. The present section is based on two nineteenth century statutes, one enacted in 1813 and one in 1853. The 1813 statute was drafted in response to a Senate resolution "that a committee be appointed to inquire what legislative provision is necessary to prevent multiplicity of suits or processes, where a single suit or process might suffice for the administration of justice in any cause to which the United States may be party, or before any court of the United States."43 In the context of these two statutes the meaning of section 1927 becomes clearer. The 1813 statute read:

That whenever causes of like nature, or relative to the same question shall be pending before a court of the United States or of the territories thereof, it shall be lawful for the court to make such orders and rules concerning proceedings therein as may be conformable to the principles and usages belonging to courts for avoiding unnecessary costs or delay in the administration of justice, and accordingly causes may be consolidated as to the court shall appear reasonable. And if any attorney, proctor, or other person admitted to manage and conduct causes in a court of the United States or of the territories thereof, shall appear to have multiplied the proceedings in any cause before the court so as to increase costs unreasonably and vexatiously, such person may be required by order of court to satisfy any excess of costs so incurred.44

The 1852 statute provided that:

Whenever two or more indictments, suits or proceedings, are or shall be prosecuted, which should be joined, the district attorney prosecuting them shall be paid but one bill of costs for all of them; and if any attorney, proctor, or other person admitted to manage or conduct causes in any court of the United States, or of the Territories thereof, shall appear to have multiplied the proceedings in any cause before such court, so as to increase costs unreasonably and vexatiously, such person may be required, by order of the court, to satisfy any excess of costs so increased. ${ }^{45}$

Even if it should be decided that by subsequent re-enactment Congress has changed the meaning of "muitiplies the proceedings" it is still necessary to confront the term "vexatiously." Vexatiously implies not only willfulness, but malicious willfulness. In the Bardin case the refusal of the attorney to proceed to trial might be treated as vexatious. But the circuit court described the unpreparedness of the attorney simply as "diliatory conduct." 46 However it is interpreted, section 1927 is not a sufficient basis for the Second Circuit's action in Bardin. A rationalization, if there is one, must be found elsewhere.

4326 AnNals of Congress 29 (1813).

443 Stat. 21 (1813).

4510 Stat. 162 (1853).

46298 F.2d at 239 . 


\section{The CONTEMPT POWeR}

Attorneys are subject to the contempt and disciplinary powers of the courts. Although contempt may be grounds for discipline, the two are not the same. The contempt power is designed to "vindicate the authority of the court," the disciplinary power "to preserve and protect the court and the public from the official ministration of persons unfit . . ." 47 Though infractions of calendar orders challenge the authority of the court and reflect upon the fitness of the attorney, neither judicial authority nor professional responsibility has been so seriously threatened as to warrant imprisonment or disbarment. But if federal district courts do have the power to fine an attorney it must arise as an exercise of one of these two powers.

The judges of the Third Circuit unanimously agreed that the conduct of the attorney in the Gamble case did not amount to contempt because it was not intentional.48 Although there are a few decisions which imply that contemptuous conduct need not be intentional, 49 almost all of the cases agree that it is a requisite element. 50 The federal contempt statute, however, is itself ambiguous on this point:

A court of the United States shall have power to punish by fine or imprisonment, at its discretion, such contempt of its authority, and none other, as-

(1) Misbehavior of any person in its presence or so near thereto as to obstruct the administration of justice;

(2) Misbehavior of any of its officers in their official transactions;

(3) Disobedience or resistance to its lawful writ, process, order, rule, decree or command. 51

47 In re Schofield, $362 \mathrm{~Pa} .201,215,66$ A.2d 675,682 (1949). The court held that an attorney could be punished by a reprimand for conduct that was contemptuous even though the trial court had failed to proceed against him for contempt. The distinction was also made in Ex parte Robinson, 86 U.S. (19 Wall.) 505 (1873).

48307 F.2d at 731, 733, 736, 737.

49 Univis Lens Co. v. United Elec. Workers, 152 Ohio St. 422, 89 N.E.2d 658 (App. Ct. 1949) held that intent was not necessary in cases of direct contempt. And in Cartwright's Case, 114 Mass. 230, 232 (1873) a bankruptcy receiver was held properly adjudged in contempt of court upon an information charging that he had "been guilty of gross negligence and malfeasance in the duties of his said office...." The real issue of the case, however, was whether good faith is a defense to a contempt charge based on intentional mishandling of funds.

50 Punishment for contempt has been held improper where a witness unintentionally failed to appear on time through confusion, Application of Burns, 161 Cal. App. 2d 137, 326 P.2d 617 (1958); and where a defendant admitted on cross-examination that his testimony on direct was false in the absence of "an admission that it was willfully false or ... circumstances ... . 'such that the court can as a matter of law' so hold." People v. Bialek, 31 IIl. App. 2d 281, 296, 175 N.E.2d 278, 285 (1961). In Ex parte Dowdle, 165 Tex. Crim. 536, 309 S.W.2d 458 (1958) a mistrial in a capital felony case occurred when a juror was released to go home to care for his children because the babysitter was ill and a replacement unavailable. He went instead to the Notre Dame-S.M.U. football game. His contempt conviction was reversed in the absence of a showing of an intentional, pre-conceived plan.

5118 U.S.C. $\S 401$ (1958). 
The third subsection clearly requires an intent. 52 But the sharp contrast between the use of the term "disobedience" in the third subsection and the term "misbehavior" in the first two subsections raises a presumption that different mental states were meant. A reasonable interpretation would be that intent is required in the third subsection whereas the first two refer to negligent or inadvertent conduct. One way to avoid this reading of the statute would be to say that the use of the term "contempt" in the introductory phrase implies a standard of intent ${ }^{53}$ that controls the following subsections. Whether or not a court would actually read the statute in this way when confronted with the problem is difficult to say. But it is possible to say that neither of the first two subsections applies to the type of situation here under consideration.

The failure of an attorney to appear before the court or to file a paper on time would not be an act within the reach of subsection 1 because it would not occur within the "presence" of the court. In Nye v. United States" the Supreme Court overruled the "reasonable tendency" interpretation of "so near thereto as to obstruct the administration of justice" established in the case of Toledo Newspaper Co. v. United States ${ }^{55}$ and substituted for a causation test a test of physical proximity. Certainly a failure to appear or file does not occur within the physical proximity of the court, although it might very well be interpreted as having a "reasonable tendency" to obstruct the administration of justice. Only California has held that a failure to appear amounts to contempt within the presence of the court and hence contempt subject to summary punishment. In Lyons v. Superior Court56 a summary contempt penalty inflicted upon an attorney for a criminal defendant when he appeared at 2:45 for a 2 o'clock court session was upheld. Without explicitly abandoning a physical proximity standard, the California Supreme Court reasoned "that the trial and the attorney's participation in it are in the court's immediate view and presence and, obviously, petitioner's obstruction of the trial by absenting himself from the court is just as directly within the view and presence and knowledge of the court as would be any other conduct

52 Russell v. United States, 86 F.2d 389 (8th Cir. 1936); United States v. Jones, 63 Fed. 951 (D.C. Cir. 1894).

53 This was the approach of Mr. Justice Jackson to the term "larceny" in Morrissette v. United States, 342 U.S. 246 (1952). "[W] accumulated the legal tradition ... it presumably knows and adopts the cluster of ideas that were attached to each borrowed word in the body of learning from which it was taken. ..."Id. at 263 .

54313 U.S. 33 (1941). The lower court had held the appellant in contempt for using liquor to induce a mentally feeble plaintiff in a pending civil action to abandon suit. These acts took place 100 miles from the courthouse. The Supreme Court reversed.

55247 U.S. 402 (1918).

5643 Cal. $2 \mathrm{~d} 755,278$ P.2d 681 (1955). The court reaffirmed the view enunciated in the Lyons case in Chula v. Superior Court, 57 Cal. 2d 199, 18 Cal. Reptr. 507, 368 P.2d 107 (1962). Both Lyons and Chula were attorneys for criminal defendants. 
by him during, and directly affecting, the trial."57 The California view, however, is accepted in no other jurisdiction and has been the subject of considerable criticism. ${ }^{58}$ On the basis of the Nye decision, then, it would seem that the negligent failure of an attorney to file a paper or attend a court session would not fall within subsection 1 of the contempt statute.

Subsection 2, on its language, is directly applicable. But the Supreme Court held in Cammer v. United States59 that the term "officer" does not apply to attorneys, but only to "officers" in the sense of bailiffs, clerks or marshals of the court. The Court based its holding on the legislative history of the statute. 60 Passed originally in 1831, the act arose out of a cause célèbre involving abuses of the broad, undefined power of the inferior federal courts under the Judiciary Act of 1789.61 James H. Peck, a federal district judge, had disbarred and ordered imprisoned an attorney who had published a criticism of one of his opinions in a case that was pending on appeal. Impeachment proceedings against Judge Peck failed, but as a result of the furor the contempt statute was passed. The Supreme Court in the Cammer case concluded that the statute was passed to prevent abuses of this kind, and that therefore "officers" was not meant to include attorneys since almost any moderately broad construction of "misbehavior" and "official transaction" would subject attorneys to the very exercise of power complained of in the impeachment proceedings against Judge Peck.62

This leaves only subsection 3 as possibly applicable to a failure to appear or to file a paper on time. If the dereliction were intentional it would fall within the requirement of "disobedience" and would be punishable as contempt upon notice.63 But an intentional failure to comply with a court calendar order is not the kind of conduct with which this comment is concerned. Perhaps if an attorney were to be continually derelict, and after re-

5743 Cal. 2d at 759-60, 278 P.2d at 683.

58 See the dissenting opinion of Traynor, J. in Chula v. Superior Court $57 \mathrm{Cal} .2 \mathrm{~d}$ at 208, $18 \mathrm{Cal}$. Reptr. at 513, 368 P.2d at 113, and the cases and articles cited therein. In Izuro v. The Queen, [1953] 2 Weekly L.R. 700, 705 (P.C.) it was held that absence of counsel from court was "clearly discourteous ... but in their Lordships' opinion it cannot properly be placed over the line that divides mere discourtesy from contempt."

59350 U.S. 399 (1956).

60 The history of the contempt statute of 1831 is summarized in Nye v. United States, 313 U.S. 33, 44-46 (1941) and Camner v. United States, 350 U.S. 399, 405-07 (1956). See also Frankfurter \& Landis, Power of Congress Over Procedure in Criminal Contempts in "Inferior" Federal Courts-A Study in Separation of Powers, 37 HARV. L. REv. 1010, 1023-38 (1924).

61 \$ 17: "And be it further enacted, That all the said courts of the United States ... shall have power ... to punish by fine or imprisonment, at the discretion of said courts, all contempts of authority in any cause or hearing before the same..." 1 Stat. 73, 83 (1789).

62350 U.S. at 407.

${ }^{63}$ Rule 42 of the FED. R. CRIM. P. provides that contempts not occurring in the actual presence of the court may be disposed of only upon notice and hearing. 
peated warnings still failed to comply with calendar orders through "oversight," the court would be entitled to presume that the attorney was in fact disobedient. But what of the attorney who fails to comply only occasionally? Such occasional derelictions, when multiplied by the number of attorneys with cases before the court, would materially impede the speedy disposition of cases. This result would obtain without any one attorney having a particularly bad record. Nor would the fact that an attorney intentionally took too many cases knowing that he would not be able to comply with all the court calendar orders involved make his conduct disobedient. Certainly the disobedience required is disobedience of the particular court order involved. Knowledge that he might fail to comply with some of the orders does not constitute knowledge that he will fail to comply with any particular order. The contempt power is not adequate to deal with the problem.

\section{The Disciplinary Power}

Compliance with calendar orders is a matter of professional responsibility. Canon 21 of the A.B.A. Code of Professional Ethics provides that: "It is the duty of the lawyer not only to his client, but also to the Courts and the public to be punctual in attendance, and to be concise and direct in the trial and disposition of causes."'65 In practice, the federal district courts have exercised the disciplinary power over attorneys admitted to their bar. ${ }^{66}$ Whether or not the disciplinary power is an "inherent" judicial power that cannot be limited bj $_{3}$ legislative action is a question that need not be discussed here. ${ }^{67}$ Certainly it is not to be doubted that standards for the exercise of the power may be en-

65 Canon 21 was the basis in part of a reprimand administered to an alcoholic attorney who was repeatedly absent from court. In re Wren, 79 Ariz. 187, 285 P.2d 761 (1955). For a discussion of negligent conduct as a basis for disciplinary action see Note, Negligence or Incompetence of an Attorney as Grounds for Disbarment or Suspension, 30 NOTRE DAME LAw. 273 (1955).

66 The uniform local court rules recommended by the Judicial Conference recognize this power. Rule 1(e) provides that "any member of the bar of this court may for good cause shown and after an opportunity has been given him to be heard, be disbarred, suspended from practice for a definite time, reprimanded, or subjected to such other discipline as the court may deem proper." 4 FED. RulES SERV. 1022 (1940).

67 Such a position was taken in In re Cannon, 206 Wis. 374, 240 N.W. 441 (1932) holding that the legislature could not by the passage of an act provide for the admission of a particular attorney to the bar. As one of two alternative grounds for this result the court states that "there is no legislative power to compel courts to admit to their bars persons deemed by them unfit to exercise the perogatives of an attorney at law." Id. at 397-98, 240 N.W. at 450. The Supreme Court reached a similar conclusion in Ex parte Garland, 71 U.S. (4 Wall.) 333 (1866). In that case Congress had prescribed an oath for attorneys which read in part: "That the deponent has never voluntarily borne arms against the United States since he has been a citizen thereof...." Id. at 376. The Court held the oath invalid both as an ex post facto law and as congressional regulation of a judicial function. Speaking for the majority Mr. Justice Field wrote that "their [attorneys'] admission or their exclusion is not the exercise of a mere ministerial power. It is the exercise of judicial power...." Id. at 378-79. 
acted by the legislature. 68 However, the regulation of attorneys practicing before a court is a necessary part of the carrying on of a court's business, and in the absence of congressional action on the subject it has been assumed that federal district courts in fact have the power. 69 The line to be drawn between that which is "judicial" and that which is "legislative" is a difficult one. ${ }^{70} \mathrm{Per}$ haps an analogy to the area of contempt would be helpful. The regulation by Congress of the contempt power is a proper exercise of its legislative power. ${ }^{71}$ But it can hardly be maintained that if Congress had not spoken, the courts would not have the power to punish for contempt. Surely the very grant of jurisdiction would imply the power of a court to enforce its orders. Does not the grant of jurisdiction similarly imply that the court can exercise the disciplinary power ${ }^{72}$ Nor are federal district courts constrained to follow the

68 In re Cannon, supra note 67 , at $397,240 \mathrm{~N}$.W. at 450 , concedes that "the legislature may legislate with respect to the qualifications of attorneys ...." But the court described the legislature's power in this respect as "incidental merely to its general and unquestioned power to protect the public interest," not an exercise of "any power possessed by it to deal exclusively with the subject of the qualifications of attorneys . . . " Ibid.

69 Ex parte Burr, 22 U.S. (9 Wheat.) 529 (1824) (Marshall, C.J.). "On one hand, the profession of an attorney is of great importance to an individual, and the prosperity of his whole life may depend on its exercise. The right to exercise it ought not to be capriciously taken from him. On the other, it is extremely desirable that the respectability of the bar should be maintained, and that its harmony with the bench should be preserved. For these objects, some controlling power, some discretion, ought to reside in the Court.... Some doubts are felt in this Court respecting the extent of its authority as to the conduct of the Circuit and District Courts towards their officers; but without deciding on this question, the Court is not inclined to interpose.... The power is one which ought to be exercised with great caution, but which is, we thirk, incidental to all Courts, and is necessary for the preservation of decorum, and for the respectability of the profession." Id. at 530-31.

70 "The accumulated weight of repetition behind such a phrase as 'inherent powers' of the lower Federal courts is a constant invitation to think words instead of things. It is imperative, therefore, to subject it to careful scrutiny. This we have ventured to do by refusing to regard the word 'inherent' as a barrier to further inquiry. Whence and why do the powers 'inhere' which are claimed to 'inhere' in the inferior Federal courts? Do they 'inhere' in nature, so that to deny these powers and yet to conceive of courts is a self-contradiction? Do they 'inhere' in our history, so that the formulated experience of the past embodies them? Do they 'inhere' in the idea of a court's usefulness, so that the courts would otherwise obviously fail in the work with which they are entrusted? These are the tests-analysis, history and social utility - which have been applied in order to ascertain to what extent the discretionary power of Congress to 'constitute Tribunals inferior to the Supreme Court' is predetermined by the 'judicial power' entrusted to them upon their creation." Frankfurter \& Landis, supra note 60, at 1022-23.

71 Ex parte Robinson, 86 U.S. (19 Wall.) 505, 510-11 (1873).

72 This power could also be implied from 28 U.S.C. $\$ 2071$ (1958) which provides that "all courts established by Act of Congress may from time to time prescribe rules for the conduct of their business." Judge McLaughlin speaking for the court in Gamble v. Pope \& Talbot, Inc., 307 F.2d 729, 732 (3d Cir. 1962) inferred that the Supreme Court could promulgate a rule providing for an attorney fine under the provisions of 28 U.S.C. $\$ 2072$ (1958). If such a rule would fall under the power to prescribe "the forms of process, writs, pleadings, and motions, and the practice and procedure of the district courts" of $\$ 2072$ then it would certainly fall under the power of the district courts granted in $\$ 2071$ to "prescribe rules for the conduct of their business." The district courts are left free to exercise their power under 
dictates of the state bar associations. While this is the usual practice, ${ }^{73}$ it is not a necessary one. ${ }^{74}$ Federal district courts are free to exercise the disciplinary power on their own.

The nature of the punishment that may be inflicted by use of the power to discipline is unclear. Normally, this power is exercised by means of disbarment, suspension or reprimand.75 A few states regularly require the errant attorney to pay at least a portion of the costs of the disbarment prosecution. 76 And a nineteenth century Supreme Court case stated that disbarment should never be imposed "where any punishment less severe-such as reprimand, temporary suspension, or fine-would accomplish the end desired."77 This statement has been faithfully repeated in Corpus Juris 78 and numerous opinions. 79 Although only one case in which an attorney has been fined as an aspect of a disciplinary proceeding has been found, 80 the feeling that a fine could be imposed if it were the appropriate penalty pervades the cases.

Such a fine would not necessarily be criminal in nature and hence open to the objection that there is no federal common law of crimes. The United States Code recognizes a category of fines known as "civil penalties" 81 which are

$\S 2071$ by rule 83 of the FED. R. Crv. P. which provides that: "Each district court . . . may from time to time make and amend rules governing its practice not inconsistent with these rules."

73 E.g., recommended uniform local court rules: "Any person who is a member in good standing of the bar of (1) the highest court of this state or of (2) the highest court of any other state, is eligible for admission to the bar of this court .... Whenever it is made to appear to the court that any member of its bar has been disbarred or suspended from practice ... in any other court he shall be suspended forthwith from practice before this court. . . ." 4 FED. Rules SERV. 1021-22 (1940).

74 Theard v. United States, 354 U.S. 278 (1957) held that a lawyer disbarred by a state need not be disbarred by the federal district court. "The short of it is that disbarment by federal courts does not automatically flow from disbarment by state courts." Id. at 282.

75 In the American jurisdictions excluding Hawaii between Sept. 1, 1957 and Aug. 31, 1960, there were 212 disbarments, 168 suspensions, and 100 reprimands. Smith, Disbarments and Disciplinary Action: The Record for Five Years, 47 A.B.A.J. 363, 364 (1961).

76 E.g., State v. Dunham, 134 So. 2d 1 (Fla. 1961) (\$307.10); State v. Poller, 109 So. 2d 371 (Fla. 1959) (\$256.46); In re Rielly, 310 S.W.2d 524 (Ky. 1957); In re McDonald, 204 Minn. 61, 284 N.W. 888 (1939) (\$7,500); State v. Catlin, 2 Wis. 2d 240, 85 N.W.2d 857 (1957) (\$1,500). KeNTUCKY R. CT. AppeaLs 3.520 (1961) provides that: "Every final judgment which adjudges the respondent guilty of unprofessional conduct shall provide for the recovery from the respondent of all costs . . . "

77 Bradley v. Fisher, 80 U.S. (13 Wall.) 335, 355 (1871).

786 C.J. Attorney \& Client $\$ 93$ (1916); 7 C.J.S. Attorney \& Client $\$ 38$ (1937).

79 E.g., State v. Murrell, 74 So. 2d 221 (Fla. 1954); In re De Caro, 220 Iowa 176, 262 N.W. 132 (1935); Lenihan v. Commonwealth, 165 Ky. 93, 176 S.W. 948 (1915); In re Williams, 233 Mo. App. 1174, 128 S.W.2d 1098 (1939); In re Reifschneider, 60 App. Div. 478, 69 N.Y. Supp. 1069 (1901).

${ }^{80}$ State v. Rubin, 201 Wis. 30, 229 N.W. 36 (1930) (\$500).

8172 Stat. 783 (1958), 49 U.S.C. $\$ 1471$ (a)(1) (1958) provides for a $\$ 1,000$ civil penalty for violations of rules and regulations issued under the provisions of the Federal Aviation 
enforced by means of civil process. ${ }^{82}$ The Supreme Court has upheld these penalties on the ground that they serve a "remedial" function. $83 \mathrm{~A}$ similar distinction has been drawn in the disciplinary cases by the repeated insistence that disbarment is not punitive but protective. 84 The district court apparently had the remedial "fine" idea in mind in the Gamble case. The court justified the fine "in view of the time of judicial employees of the Government wasted as a result of the late filing of this memorandum," and went on to explain in a footnote that: "The assertion that the court is not inconvenienced by filing such a memorandum with the Clerk the day before the pretrial conference is inaccurate, since the trial judge in such circumstances normally would not receive the document in time to prepare for the conference. Also consideration of this Motion, etc., has been required by this delay." 85 To reason that the late filing occasioned expense because it was necessary to hold a hearing in order properly to deal with it is somewhat circular. However, this is no more circular than the position of the Supreme Court in Helvering v. Mitchell 86 that civil income tax fraud penalties could be justified on the ground that

Act. 48 Stat. 1100 (1934), 47 U.S.C. $\$ 502$ (1958) provides for civil forfeitures to the Federal Communications Commission. Section $5(l)$ of the Federal Trade Commission Act, 52 Stat. 111,114 (1938) amended 64 Stat. 21-22 (1950), 15 U.S.C. 45(1) (1958), provides for a $\$ 5,000$ civil penalty for each violation of a Commission cease and desist order.

8272 Stat. 786 (1958), 49 U.S.C. \$ 1473(b)(1) (1958): “Any civil penalty imposed under this chapter may be collected by proceedings in personam against the person subject to the penalty and, in case the penalty is a lien, by proceedings in rem against the aircraft, or by either method alone. Such proceedings shall conform as nearly as may be to civil suits in admiralty, except that either party may demand trial by jury of any issue of fact, if the value in controversy exceeds $\$ 20$, and the facts so tried shall not be reexamined other than in accordance with the rules of the common law." 50 Stat. 197 (1937), 47 U.S.C. \& 504(a) (1958) provides that: "The forfeitures provided for in this chapter shall be payable into the Treasury of the United States, and shall be recoverable in a civil suit in the name of the United States brought in the district where the person or carrier has its principal operating office or in any district through which the line or system of the carrier runs . . .."

83 Helvering v. Mitchell, 303 U.S. 391 (1938). In that case the Court held that a civil penalty for income tax fraud did not violate the double jeopardy provision of the fifth amendment even though the taxpayer had previously been acquitted in a criminal fraud proceeding. The court characterized civil tax penalties as remedial because "they are provided primarily as a safeguard for the protection of the revenue and to reimburse the Government for the heavy expense of investigation and the loss resulting from the taxpayer's fraud." Id. at 401 .

84 "The purpose of suspending or disbarring an attorney is to remove from the profession a person whose misconduct has proved him unfit to be intrusted with the duties and responsibilities belonging to the office of an attorney, and thus to protect the public and those charged with the administration of justice, rather than to punish the attorney. The idea of punishment is usually held to have no appropriate place, and no punitive sentence can be imposed." 5 AM. JuR. Attorneys at Law $\$ 249$ (1936). But courts have, upon occasion, choked on this ritual phraseology. "Punishment may not be the prime object to be accomplished in disbarment proceedings, but it cannot be questioned that disbarment is punishment." Lenihan v. Commonwealth, 165 Ky. 93, 107, 176 S.W. 948, 955 (1915). Accord In re Breidt, 84 N.J. Eq. 222, 230, 94 Atl. 214, 218 (1915).

85191 F. Supp. at 765 n.2.

86303 U.S. 391 (1938). 
such penalties were necessary to pay the cost of the fraud investigation. ${ }^{87}$ As had been pointed out by Mr. Justice Frankfurter, the rule distinguishing between civil and criminal penalties on the basis that civil penalties serve a "remedial" function depends upon "dialectical subtleties."88 Another basis for distinction might be the procedure used to enforce the "fine." It seems possible that there could be three categories of "fines": Criminal fines enforced by the threat of imprisonment, civil penalties enforced by attachment, and disciplinary "fines" imposed by suspension. After notice and hearings9 the order of the court could simply read: "Attorney Jones is suspended from the bar of this court until payment of a fine of $\mathrm{X}$ dollars for failure to comply with the calendar orders of this court." 90 If the court has the power to suspend this would seem to be a proper exercise of the power. It can hardly be argued that such a suspension is an abuse of discretion since the penalty, providing the fine is of an appropriate amount, is fitting for the attorney's breach of his professional obligation. 91

87 Quoted note 83 supra.

88 United States ex. rel. Marcus v. Hess, 317 U.S. 537, 554 (1943) (concurring opinion).

89 Notice and an opportunity for a hearing are required in a disciplinary proceeding based on acts not occurring in or near the presence of the court. In re Los Angeles County Pioneer Soc'y, 217 F.2d 190 (9th Cir. 1954). A jury trial is not required. "The provisions of the Constitution, which declare that no person shall be held to answer for a capital or otherwise infamous crime, unless on a presentment or indictment of a grand jury, and that the trial of all crimes, except in cases of impeachment, shall be by jury, have no relation to the subject in hand. ... [T]he constitutional privilege of trial by jury for crimes does not apply to prevent the courts from punishing its officers for contempt, or from removing them in proper cases. Removal from office for an indictable offence is no bar to an indictment. The proceeding is in its nature civil, and collateral to any criminal prosecution by indictment." Ex parte Wall, 107 U.S. 265, 288 (1882).

90 Such an order would be similar to that entered in In re McDonald, 204 Minn. 61, 284 N.W. 888 (1939): "We are not disposed to deal harshly with respondent, and we fix the amount he must pay petitioner [The Board of Law Examiners], before any application for reinstatement will be entered, at the sum of \$7,500." Ibid. The court observed "that no statutory authority is found for taxing costs and disbursements against a respondent in a disbarment proceeding." Ibid. A similar case is In re Cannon, 206 Wis. 374, 412, 240 N.W. 441, 456 (1932): "Upon the payment of the judgment for costs entered against Mr. Cannon in the original proceeding resulting in his suspension from practice, an order will be entered reinstating him as a member of the bar of this court."

91 The Solicitors Act, 1957, 5 \& 6 Eliz. 2, c. 27, $\S 47(2)$ (C) empowers the disciplinary committee of the Law Society to impose "a penalty not exceeding five hundred pounds, which shall be forfeit to Her Majesty." This applies only to solicitors, not to barristers. Under British administration the Supreme Court of Nigeria was empowered to make rules regulating "the discipline, employment in causes and fees of legal practitioners." $\mathrm{Ch} .211$ of the Laws of Nigeria (1948). In pursuance of this power the supreme court promulgated Rule 19 of Order 16. "Any barrister or solicitor who commits any breach of any of the said provisions of this Order or fails to comply with any of the said provisions, for which breach or non-compliance no specific penalty is provided, shall be liable for a first offence to a fine not exceeding twenty pounds, and for any subsequent offence to a fine not exceeding fifty pounds, without prejudice to the powers of the court to suspend any barrister or solicitor or strike his name off the role for professional misconduct." The text of this rule may be found in [1953] 2 Weekly L.R. at 703. 


\section{CONCLUSTON}

Gamble v. Pope \& Talbot, Inc.,92 was an unfortunate case in which to "test" the power of a court to impose a disciplinary fine. The first question that might be asked is why it is necessary to file a pretrial memorandum ten months before the pretrial conference. But not all court calendar orders are subject to such objections. Nor, at least in view of what can be gleaned from the opinions, was there any showing that the particular attorney involved had had a record of forgetful non-compliance or even that such oversights had become common among the attorneys practicing before the court. The facts as they appear in the opinions indicate that the situation in the Gamble case was in fact a rare "slip-up," and that a fine was inappropriate. The district court nonetheless felt that a fine was "required" without explaining why. $93 \mathrm{But}$ the principles enunciated by the Third Circuit in reversing the fine would foreclose such an action by a federal district court even in situations where it is needed. Perhaps the Second Circuit will further develop and rationalize its position in the Bardin case. If it does so, the imposition of such "fines" may be recognized as within the power of the courts by judicial decision.

This conclusion can be reached by arguing: First, that the contempt power is distinct from the disciplinary power. Second, that the district courts as constitutional courts possess the disciplinary power, and in the absence of legislation are free to exercise it in full-subject only to reversal upon appeal for abuse of discretion. And third, that the imposition of an attorney fine enforced by suspension is not a "criminal" but a "disciplinary" penalty. The weakness of the argument is in the interaction between the first and third points. It is simple enough to argue that discipline serves only a "protective" purpose where disbarment is involved. The courts and the public are protected from the services of the unfit when the unfit are removed from office. In cases where the disciplinary power is exercised by means of suspension, the "protective" purpose is less evident, while the purpose of punitive deterrence assumes greater significance. But a fine has no immediate protective purpose. The only possible rationale for its imposition is as deterrent punishment. Does this punitive purpose make the fine in fact a criminal penalty? If it does, then an attorney fine cannot be imposed without legislative authorization. The answer proposed is that the distinction drawn in the cases between criminal and civil penalties as "punitive" and "remedial" is inadequate, and that another important basis of distinction is the mode of enforcement of the penalty.

92191 F. Supp. 763 (E.D. Pa. 1961), rev'd, 307 F.2d 729 (3d Cir.), cert. denied 371 U.S. 888 (1962).

93 After the Third Circuit reversed, the district court applied for certiorari. Certiorari was denied under the name of United States Dist. Court for the E. Dist. of Pa. v. Mahoney. 371 U.S. 888 (1962). Only an amicus brief was filed in the Circuit Court in support of the fine. 
The process as well as the purpose is significant in determining whether a penalty is or is not criminal.

In summary, considerations of policy suggest that an attorney fine would serve a useful function in the administration of justice. Analysis suggests that a disciplinary fine is possible. But the recognition of an attorney fine would involve a departure from traditional conceptions of the disciplinary power. Furthermore, the traditional association of fines-and here euphemisms are of little real help-with the criminal makes the argument that there is such a creature as a "disciplinary fine" difficult. Ultimately, the question goes to the breadth of the disciplinary-and hence the judicial-power. In making this determination policy is arrayed against precedent, which neither specifically prohibits nor sanctions such a fine.

If the courts decide, however, to follow the pull of precedent rather than the pull of policy, then Congress might enter the field. This could be done by making provision either for a contempt or civil fine when attorneys violate court calendar orders. Either course, however, is open to objection. It seems undesirable that attorneys who have voluntarily entered the practice of law should be subject to criminal penalties as the result of oversights occurring in the course of that practice.94 On the other hand, a "civil penalty" would presumably require a jury trial, which is an awkward way for a court to enforce its orders. But could Congress make provision for a disciplinary fine? In the absence of legislation the disciplinary power, whatever that power might be, is fully vested in the courts. If the courts cannot now impose a disciplinary fine, it is difficult to see how Congress can enlarge the disciplinary power which the courts now possess in full. But the difficulty is for the most part verbal. In the absence of legislation the court must weigh its interest in achieving effective calendar control through an attorney fine against traditional conceptions of its judicial power. With statutory guidance, the court would not have to be so wary lest it tread within the legislative domain.

94 Presumably failure to pay a contempt fine would result in imprisonment. 